\title{
Evaluation of Biological Water Quality by Biological Macrophytic Index in River: Application on the Watershed of Beht River
}

\author{
Bentaibi Saloua \\ Rahou Abdelilah \\ Chillasse Lahsen \\ Faculty of Sciences, Meknes, Morocco \\ Hammada Soumaya \\ Faculty of Sciences and Technology, Beni Mellal, Morocco
}

Abba Elhassan

Superior School of Technology, Khenifra, Morocco

doi: 10.19044/esj.2017.v13n27p217 URL:http://dx.doi.org/10.19044/esj.2017.v13n27p217

\begin{abstract}
The Biological macrophytic Index for River (IBMR) is based on the examination of aquatic plants (macrophytes) to determine the river quality, particularly its degree of eutrophication linked to nitrogen content and phosphorus in water. The aim of this study was to evaluate the biological quality of a Moroccan river through the IBMR in view to integrate it into the monitoring programs of water quality. Indeed, this method of assessment of biological water quality is under development and adaptation to the Moroccan hydro-biological context. Beht River on which we selected 13 stations, the quality was evaluated during a first sampling campaign in 2014. The results show a good representation of the trophic status of stations relative to environmental conditions of the environment such as the types of wastes, agricultural and other activities. Indeed, the stations with a strong trophic level often come downstream urban areas or near farms. The low average index values correspond to stations with little to very little polluting activities.
\end{abstract}

Keywords: Water quality, Bioindication, Macrophytes, Beht river

\section{Introduction}

Morocco is the country of North Africa best provided in continental waters. The great climate and geological diversity accentuates this wealth creating varied types of aquatic ecosystems. These aquatic environments are 
the support of a large flora and fauna biodiversity and promote significant economic activities. However, these areas are subject to different ecological threats to their normal operation (Chillasse et al.,2001).It is therefore interesting to have the necessary tools to monitor their quality, considering the enormous pressure they are subjected (Berreho et al., 2006). The evaluation of the quality of surface water in Morocco so far is mainly based on the physicochemical analyzes and some bacteriological parameters.

The interest of biological indices to assess the quality of an aquatic environment lies in the possibility of having a synthetic and exhaustive vision, through an integrating compartment of this environment (Lemoalle et al., 2001). One of these compartments is the vegetation that, in addition to its role as a support and ecological habitat for many animal species, it plays a very important trophic role and is characterized by ease of observation. In France, tests to evaluate the ecological status of hydrosystems led to the development of a bio-assessment tool based mainly on aquatic vegetation, in this case the Macrophytic Index in the River IBMR in 2002 (Haury et al., 2002, 2006). In order to promote such methods in Morocco, this research has set itself targets to follow in Oued Beht,a Sebou basin river, the impact of disturbances (agricultural pollution, domestic, industrial,...) on aquatic vegetation.

\section{I.}

\section{Method}

\section{Presentation of the study area}

The watershed of Oued Beht is located north-west of Morocco and occupies an area of about 11,000 square kilometers at the southwest part of the Sebou basin. It is a left tributary of the Sebou river. The river takes its origins at the confluence of rivers Ifrane and Tigrigra in the area of Azrou. It feeds on crossing the central plateau by many tributaries such as: Bouachouch, Kharouba, Ouchket El Kell, Beregline, D'Kor and finally receives R'Dom before its confluence with the Sebou (HCEFLCD, 2006). (Figure 1) 


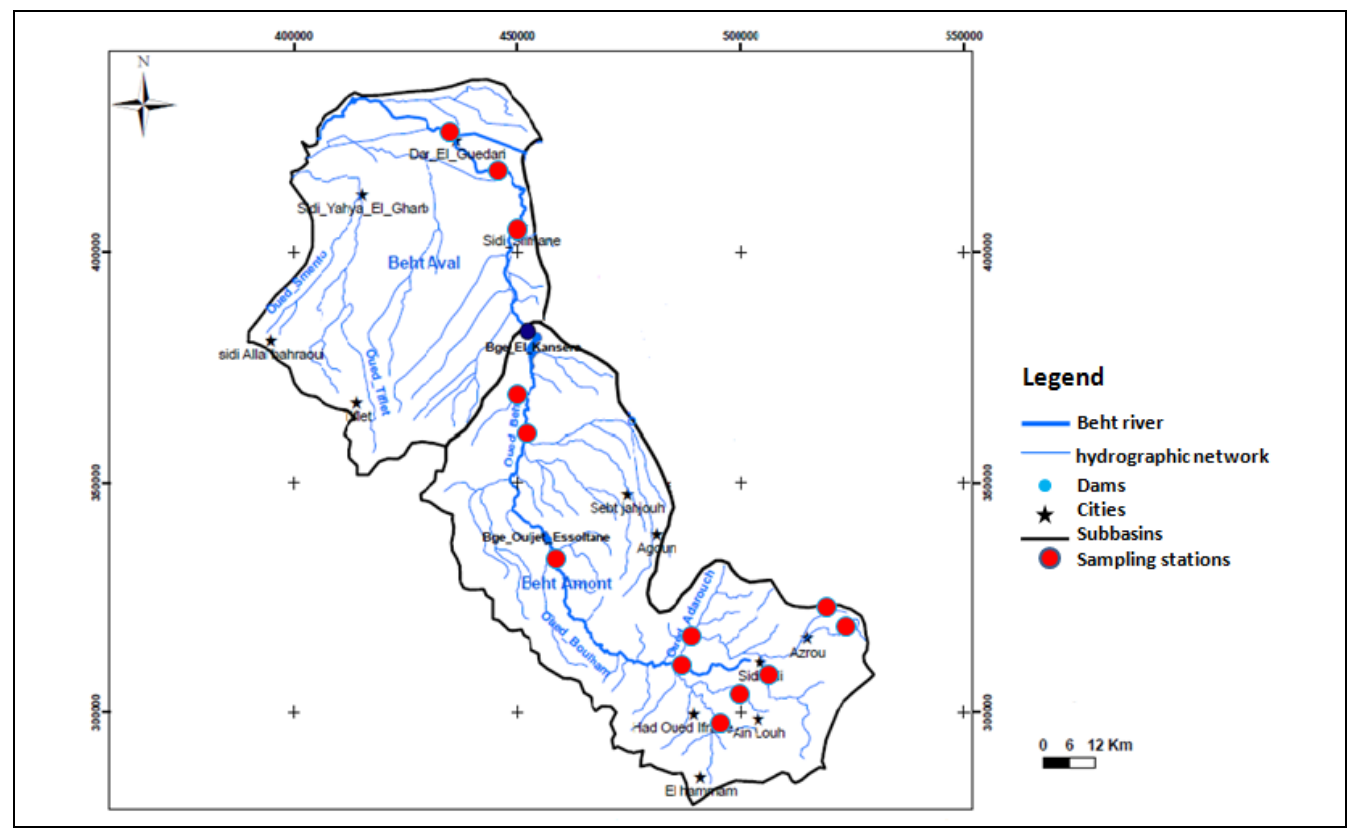

Figure 1: Location of the study area and sampling stations ABHS (2010),(amended)

\section{Choice of sampling stations}

Thirteen stations, whose morphometric characteristics meet the requirements of the standard (IBMR) were selected throughout Oued Beht. According to the AFNOR (AFNOR,2003), an IBMR station must contain, if possible, at least one lotic part (moving water) and a lentic part (stable water); lighted stations are chosen more than too shady. Moreover, the sampling stations should have a length and a sufficient surface so that the flora potential of the section will be well appreciated, including in the side of the bank.

\section{Sampling of macrophytes}

Sampling was carried out during the periods May to July 2014. Readings should be made during development of the vegetation, with clear, shallow waters. Vegetation types considered are all visible to the naked eye. The statements also involve estimates of recovery classes of each type, with identification of taxa and taxonomic sampling for verification. Then calculating the IBMR is made from the list of plants, and gives a value of 0 to 20 (AFNOR, 2003). 


\section{Calculation of the IBMR}

The IBMR is an index that takes into account the specific ecology and dispersal of the species. The formula of IBMR according to AFNOR standard (AFNOR, 2003) is:

$$
I B M R=\frac{\sum_{i}^{n} E_{i} \cdot K_{i} \cdot C S_{i}}{\sum_{i}^{n} E_{i} \cdot K_{i}}
$$

Where i: contributory species, $\mathrm{n}$ : total number of contributory species; Csi: oligotrophy specific rating from 0 to 20 ; $\mathrm{Ki}$ : abundance ratio (1 to 5 according to the coverage range and Ei dispersion coefficient (1-3 depending on the degree of dispersion).

The results of the IBMR are integrated in a grid on five levels (Table 1) (AFNOR, 2003)

Table 1: Evaluation grid according to the standard NF T 90-395 IBMR- - October 2003

\begin{tabular}{|l|l|}
\hline Evaluation grid according to the IBMR standard-NF T 90-395- oct 2003 \\
\hline IBMR $>14$ & very low \\
\hline $14 \geq$ IBMR $>12$ & low \\
\hline $12 \geq$ IBMR $>10$ & medium \\
\hline $10 \geq$ IBMR $>8$ & high \\
\hline IBMR $\leq 8$ & Very high \\
\hline
\end{tabular}

\section{Results}

Calculating the IBMR gave the following results (Table 2)

Table 2: Results of the IBMR calculation for the 13 stations

\begin{tabular}{|c|c|}
\hline Stations & Trophic level \\
\hline 1 & Low \\
\hline 2 & Medium \\
\hline 3 & High \\
\hline 4 & Veru high \\
\hline 5 & Medium \\
\hline 6 & High \\
\hline 7 & Absence of macrophytes \\
\hline 8 & Absence of macrophytes \\
\hline 9 & High \\
\hline 10 & High \\
\hline 11 & Absence of macrophytes \\
\hline 12 & Very high \\
\hline 13 & High \\
\hline
\end{tabular}

These results were included in an evaluation map for the biological quality (Figure 2) 


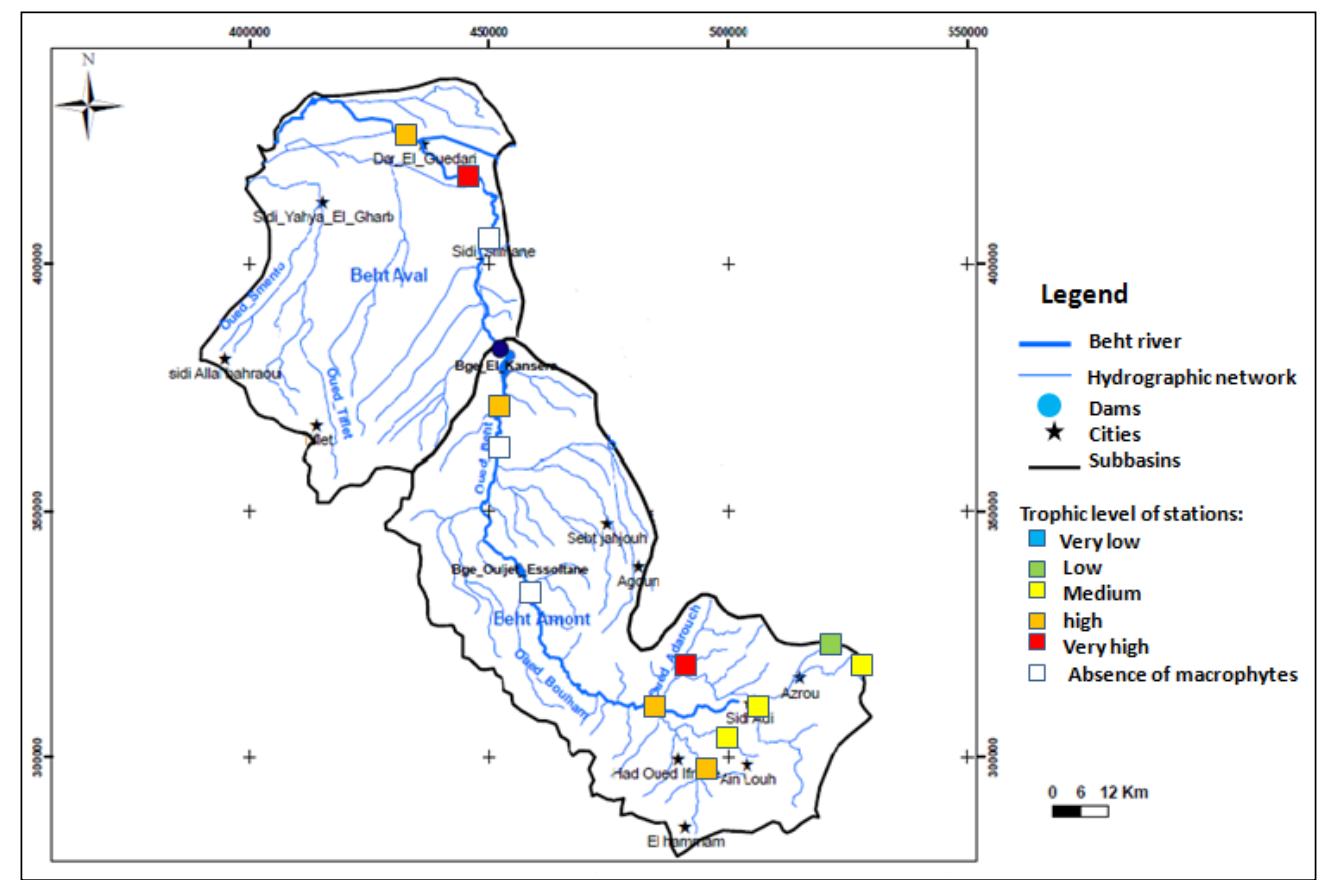

Figure 2: biological quality assessment map of the sampling stations

The plant species richness of each station is represented in a graph (Figure 3)

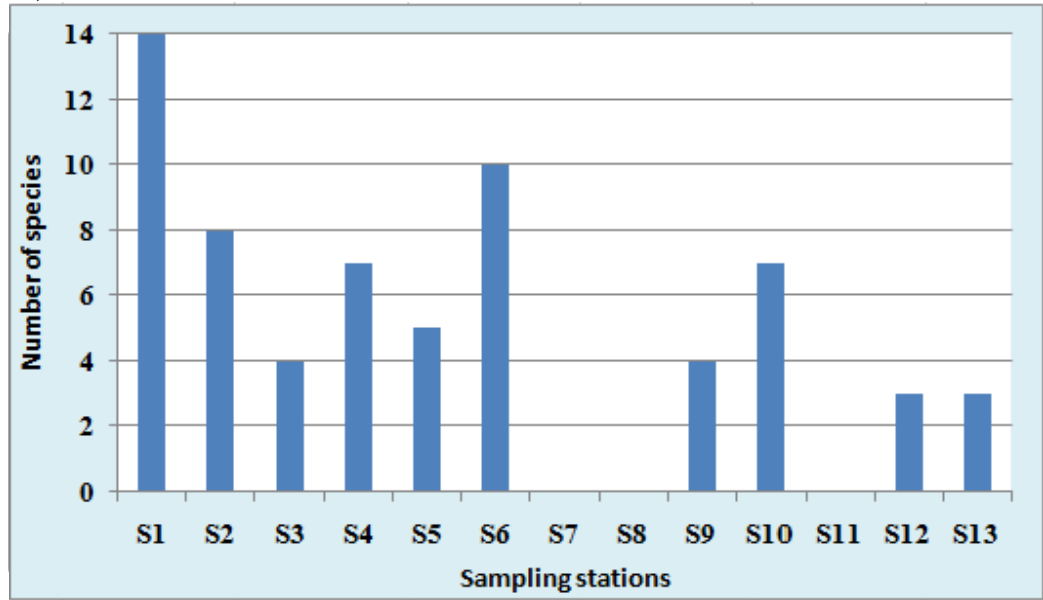

Figure 3: Specific richness of the studied stations

\section{Discussion}

The value of biological indicators to assess the quality of an aquatic environment is the ability to have a comprehensive and exhaustive vision, through an integrator compartment of this environment (Lemoalleet al., 2001). When choosing a method and exploiting results they give, must be taken into consideration that they reflect a state of a complex system, whose 
components are linked by flows of materials and energy governing the structure and operation of this system. In other words, the biological compartments depend on each other in multiple processes more or less direct, so the results of their study cannot be independent. Thus, to have an overall assessment, it must use different methods based on compartments indices (macro invertebrates, fish ...), which makes it possible to collect additional information, but without disconnecting or using them in a completely autonomous manner (Chauvin et al., 2008).

This method of evaluation of the water quality is being adapted to the Moroccan hydrobiological context. A first attempt was made in 2012 on a river Sebou Basin, Oued Boufekrane, which is less important in terms of length and hydraulic inputs that Beht but has relatively the same ecological profile as it takes born in the region of El hajeb and crosses the plain of Sais where he received releases and inputs of agricultural land and urban areas (Bentaibi et al.,2014). It also belongs to the Oued R'dom basin which is a sub-basin of the Beht.

The value of the index in station 1 indicates a low trophic level, since they are located upstream near the sources. Stand structure parameters such as species richness, learn about the biogenic capacity of the environment. These settings also show that stations 1 and 2 have relatively high species richness. The high number of species in these stations is due to the favorable conditions that characterize the environment. Within 4 and 12 stations, the very high trophic level is the result of an important nutrient loading from organic spills and the degradation of organic matter (nitrates and phosphates). The values indicating a medium trophic level of the index correspond to stations undisturbed by polluting activities. Stations with high trophic level $(3,6,9,10$ and 13) just downstream of urban areas or near farms (strong contribution of fertilizer). In stations where there is lack of macrophytes, the water is very turbid and deep.

\section{Conclusion}

This work aimed mainly to test one of the methods using macrophytes, namely IBMR to assess the biological quality of Moroccan river water. Organic IBMR index clearly reflects the impact of domestic waste and polluted effluents from domestic and industrial waste water in the stations located downstream. Going back upstream is the impact of agricultural activities that affect water quality. Moreover, it turned out that the IBMR may be applicable and significant in the Moroccan context since the index values obtained seem logical in relation to the location and impact which is subject studied each station. A possible generalization of the use of IBMR to assess the biological quality of watercourses at the national level, as is the case for biotic indices based on macro-invertebrates and diatoms, is 
dependent on the conduct of in-depth studies similar to those carried out in other countries already engaged in this field.

\section{References:}

1. ABHS (2010),:Agence du Bassin Hydraulique de Sebou,Maroc, Etude de mise en place d'un système d'alerte aux crues et de télémesure dans le bassin du Beht.

2. AFNOR, 2003. Norme NF T90-395, Octobre 2003. Qualité de 1'eau. Détermination de l'Indice Biologique Macrophytique en Rivière (IBMR), Association Française de Normalisation (AFNOR). 28 p.

3. BENTAIBI S., CHILlASSE L., ABBA E., HAMMADA S.,2014, Contribution to the biological assessment of quality surface waters trough the macrophyte biological index for rivers (IBMR) in Boufekrane river " in International Journal of Advanced Life Sciences, IJALS, Volume (7) Issue (4) November - 2014.

4. BERRAHO A., BIROUK A. MENIOUI M., 2006. Biodiversité et équilibres écologiques GT8-4 : 129-131.

5. HCEFLCD (2006) :Haut Commissariat aux Eaux et Forets et Lutte Contre la Désertification, Maroc, Etude d'aménagement du bassin versant de l'oued Beht en amont du barrage El Kansera.

6. CHAUVIN C., PELTRE M-C., HAURY J., 2008, La bioindication et les indices macrophytiques, outils d'évaluation et de diagnostic de la qualité des cours d'eau, INGENIERIE numéro spécial, p : 91-108.

7. CHILLASSE L., DAKKI M., ABBASSI M., 2001.Valeurs et fonctions écologiques des Zones humides du Moyen Atlas, Humedales Mediterráneos, 1 (2001) 139 - 146 SEHUMED, Valencia (España) ISSN $1137-7755$.

8. HAURY J. , PETER M-C., TERMOLIERES M., BARBE J., THIEBAUT G., BERNEZ I., DANIEL H., CHATENET P., MULLER S., DULARTRE A., LAPLACE-TREYTURE C., CAZAUBON A., LAMERT-SERVIEN E., 2002, Uune méthode pour mettre en évidence la trophie de l'eau et de la pollution organique avec les macrophytes : l'indice biologique macrophytique en rivière (IBMR)_Applicatuion à différents types de rivières et de pollutions, 11ème Symposium EWRS, Moliets et Maa (France), sept 2002.

9. HAURY J. , PETER M-C., TERMOLIERES M., BARBE J., THIEBAUT G., BERNEZ I., DANIEL H., CHATENET P., HAANE-ARCHIPOF G., MULLER S., DULARTRE A., LAPLACE-TREYTURE C., CAZAUBON A., LAMERT-SERVIEN E., 2006, A new method to access water trophy and organic pollution- the Macrophite Biological Index for Rivers (IBMR) : its 
application to different types of river and pollution, Hydrobiologia, vol. 1, p. 153-158.

10. LEMOALLE J., BERGOT F., ROBERT M., 2001, état de santé des écosystémes aquatiques. De nouveaux indicateurs biologiques. Synthèse du programme de recherche 1996 1999, Rapport GIP Hydrosystéme Ministère de l'environnement, Cemagref éditions, 75 p. 